before. On February 20-three months after the first onsethaving free time, I took the field again using a $1 \mathrm{~mm}$. object on a Priestley Smith's scotometer. To my surprise it had improved considerably. There was still a small absolute scotoma below fixation, but over the rest of the field the object could be seen almost everywhere. It was not quite clear but flashed in and out in some regions; no other definite scotomata could be mapped. This was confirmed at the Hospital on a metre screen with a $2 \mathrm{~mm}$. object.

I had expected that the defect would be permanent, and this improvement was unforeseen. It seems probable that the " new " lateral vessels which $\mathrm{Mr}$. Martin Jones saw, bringing the blood to the part, had prevented complete destruction of the retinal elements which had retained and had to some extent recovered power.

I have never seen or read of a case quite like this, and in view of its fortunate ending it seemed worth while to publish this record.

I have much to thank Mr. Martin Jones for. I have little doubt that his prompt action saved me from a much larger loss of field, and he has given me much help in the recording of the case.

\title{
MYCETOMA OF THE EYELID
}

BY

\section{J. S. ALDRIDGE and R. KIRK}

SUDAN MEDICAL SERVICE

THE following case is of interest because of the extreme rarity of the condition. Elliot (1920) in his "Tropical Ophthalmology" states that during the many years of his experience in Madras he neither saw nor heard of a single instance of mycetoma occurring in the eye or its neighbourhood, adding, however, that as the condition has been described, it would be well worth while for tropical practitioners to be on the look out for any further instances of this rare condition. One case. was observed in 1937 at the Giza Memorial Ophthalmic Laboratory in Cairo (Wilson, 1938), and the only other case known to the present writers is one reported by Christopherson and Archibald (1919), in which the granuloma occurred in the lacrymal gland. It is interesting to observe that this latter case came from approximately the same region of the Northern Sudan as the present one. 


\section{Case History}

The patient, Saida Abdou, was a girl aged approximately four years, of Nubian race, from Sonki in the district of Halfa. She came to Wadi Halfa civil hospital complaining of a tumour of the left eyelid, of two months' duration. Examination revealed a tumour about the size of a marble, situated in the upper eyelid, at the outer angle, and passing up under the orbital ridge. It was more prominent on the skin surface than on the conjunctival surface. There was no tenderness; the overlying skin was normal and not attached to the growth. The tumour was removed through a skin incision and transferred to a ten per cent. formol saline solution for histological examination.

\section{Pathological Histology}

Paraffin sections of this tissue showed the morbid histological changes commonly associated with a fungus infection. The tissue was the seat of a chronic non-specific inflammatory lesion, characterised by hyaline fibrosis, plasma-cell and leucocytic infiltration,

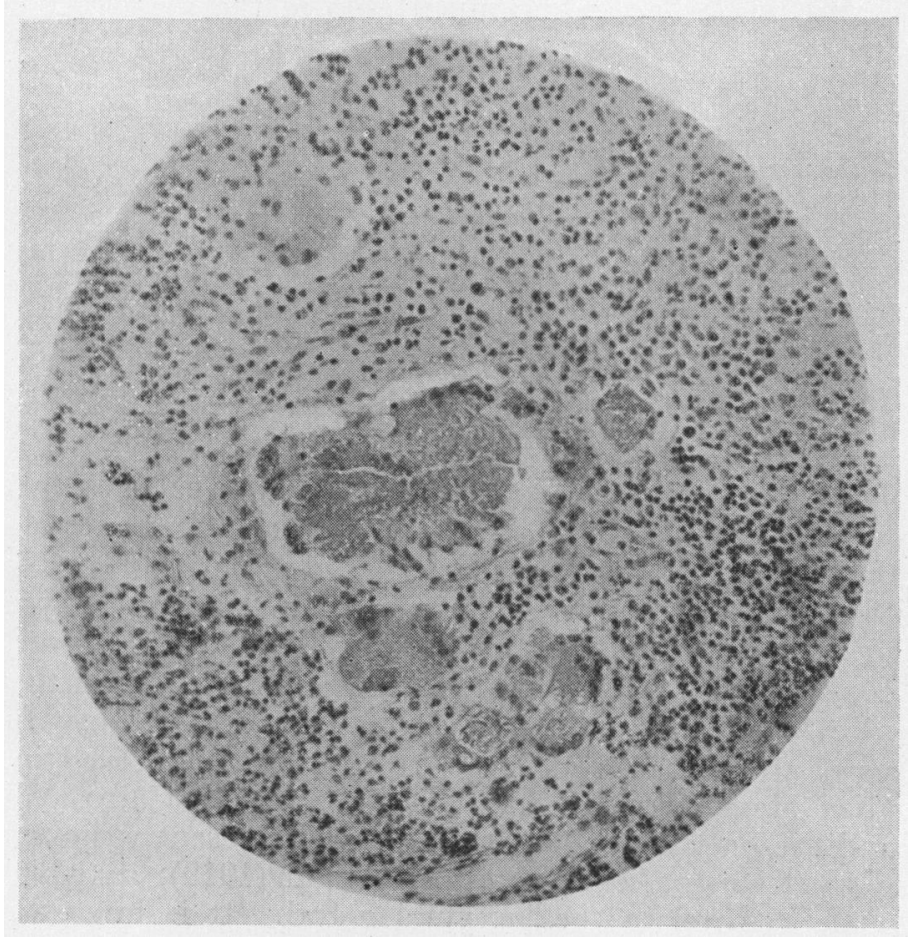

Mycetoma of the Eyelid.- Section of the granuloma showing the fungal grains in situ. $\times 200$ 
with occasional small imperfect giant-cell formations, and in the more densely infiltrated parts fungal grains could be seen irregularly distributed (see figure). Little in the way of detailed structure could be made out in the grains, and any attempt to culture them was obviously out of the question, but their appearance and relation to the associated histopathological changes are sufficiently typical to establish a diagnosis of mycetoma.

Acknowledgment.-We are indebted to the Director of the Sudan Medical Service for permission to publish this case.

\section{REFERENCES}

Christopherson, J. B. and Archibald, R. G. (1919).-Proc. Roy. Soc. Med., Vol. XII (Section of Ophthalmology), pp. 4-14.

Elliot, R. H. (1920).- Tropical Ophthalmology. London: Henry Frowde and Hodder and Stoughton.

Wilson, R. P. (1938).-12th Rep. Giza Memorial Ophthalmic Laboratory, p. 70. Cairo: Ministry of Public Health.

\section{THE DEVELOPMENT OF OPHTHALMOLOGY IN BOMBAY}

BY

LT.-Col. Sir J. N. Duggan, KT., C.I.E., O.B.E.,

D.O.(Oxon.), F.C.P.S., L.M. \& S.

PROFESSOR OF OPHTHALMOLOGY, GRANT MEDICAL COLLEGE, AND OPHTHALMIC SURGEON, SIR C. J. OPHTHALMIC HOSPITAL, BOMBAY

and

V. K. Chitnis, D.O.(Oxon. \& Bom.), M.B., B.S., F.C.P.S. HON. ASSISTANT SURGEON, SIR C. J. OPHTHALMIC HOSPITAL, BOMBAY

\section{Introductory}

THE origin and development of ophthalmology in the Bombay Presidency are closely bound with the establishment and growth of its medical institutions. No record, proving that ophthalmology was practised on scientific lines was available before these institutions came into existence. Even after the establishment of the Grant Medical College and the J. J. Hospital, it took some time for the teachers to evolve the different courses of instruction imparted in the institutions. Ophthalmology was considered as a minor branch of surgery and hence the course was limited to a couple of lectures delivered to the first batch of students of the College. It must, however, be said that the importance of this 